CASE NOTE

\title{
ROBERT JOHN PENESSIS $v$ UNITED REPUBLIC OF TANZANIA (JUDGEMENT) (AFRICAN COURT ON HUMAN AND PEOPLES' RIGHTS, APP NO.013/2015, 28 NOVEMBER 2019)
}

Bronwen MANBY* AND Clement BERnARdo MubangA ${ }^{\dagger}$

TABLE OF CONTENTS

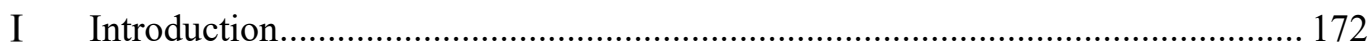

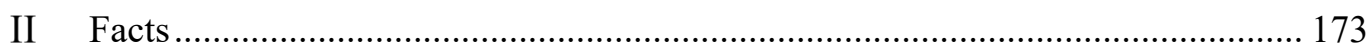

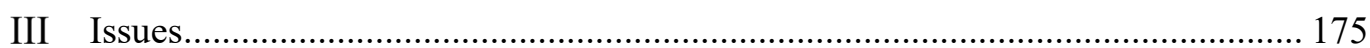

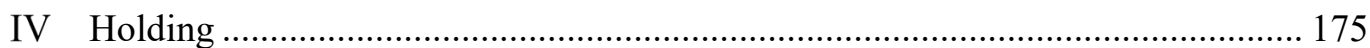

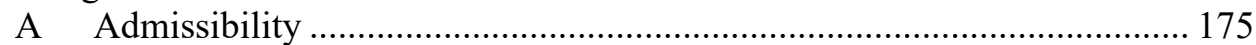

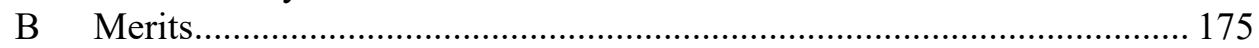

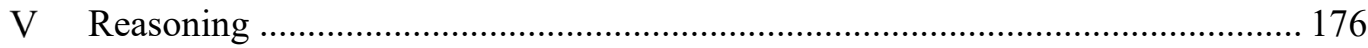

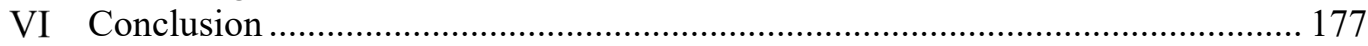

\section{INTRODUCTION}

Robert John Penessis $v$ United Republic of Tanzania (Judgement) ('Penessis') ${ }^{1}$ is the second case decided by the African Court on Human and Peoples' Rights ('African Court') that considers the right to a nationality. The judgment builds on the African Court's decision in Anudo Ochieng Anudo v Tanzania ('Anudo'), ${ }^{2}$ as well as the existing jurisprudence from the African Commission on Human and Peoples' Rights ('African Commission'), and the African Committee of Experts on the Rights and Welfare of the Child. ${ }^{3}$ The African Court ruled that Tanzania

* Bronwen Manby is a Senior Policy Fellow at the London School of Economics and Political Science, and an independent consultant. She previously worked for the Open Society Foundations and Human Rights Watch. She has written extensively on statelessness and the right to a nationality in Africa, and her book Citizenship in Africa: The Law of Belonging was published by Hart Publishing in November 2018.

$\dagger \quad$ Clement Bernardo Mubanga is a PhD Student at the Open University of Tanzania, his thesis is titled 'Determination and Proof of Tanzanian Citizenship'. His book is titled Accessing Tanzania Immigration Services: A Question and Answer Guide Book published by Nesmap Printing Technology in May 2018. Email: mubangakiganda@gmail.com.

1 (African Court on Human and Peoples' Rights, App No.013/2015, 28 November 2019) ('Penessis').

2 Anudo Ochieng Anudo v Tanzania (Judgment) (African Court on Human and Peoples' Rights, App No.012/2015, 22 March 2018) ('Anudo'). See discussion in Bronwen Manby, 'Anudo Ochieng Anudo v Tanzania (Judgment) (African Court on Human and Peoples' Rights, App No 012/2015, 22 March 2018)' (2019) 1(1) Statelessness and Citizenship Review 170.

3 See generally Bronwen Manby, Citizenship in Africa: The Law of Belonging (Hart 2018); Bronwen Manby, Citizenship Law in Africa: A Comparative Study (Open Society Foundations, $3^{\text {rd }}$ ed, 2016). 
had arbitrarily deprived the applicant of his nationality and curtailed his rights of liberty and freedom of movement.

Tanzania was among the few African states that have made a declaration provided for under art 34(6) of the Protocol to the African Charter on Human and Peoples' Rights, which establishes the African Court's competence to directly receive petitions from individuals. ${ }^{4}$ The government has, however, since withdrawn this declaration. ${ }^{5}$

The African Court has jurisdiction to interpret any human rights obligations binding on the state, ${ }^{6}$ and in Penessis thus draws on the African Charter on Human and Peoples' Rights ('African Charter'), ${ }^{7}$ the International Covenant on Civil and Political Rights, ${ }^{8}$ and the Universal Declaration of Human Rights ('UDHR'). ${ }^{9}$

The African Court affirmed that the UDHR is part of customary international law, in particular art 15 on the right to a nationality. ${ }^{10}$ The judgment cements the holding that where a person has been issued documents recognising nationality, the burden of proof is incumbent upon the State to prove that he was not a national. ${ }^{11}$ Finally, adding to the findings in Anudo, the African Court drew on African Commission jurisprudence to confirm that the protection of 'legal status' in art 5 of the African Charter includes the right to a nationality.

\section{FACTS}

The applicant in the case, Robert John Penessis, was arrested by the Tanzanian immigration authorities on 8 January 2010, on the grounds of alleged illegal entry and presence in Tanzania. ${ }^{12}$ On 17 January 2011 he was charged, convicted and sentenced by the Kagera Magistrates' Court to a fine of 80,000 Tanzanian shillings or, if in default, two years' imprisonment and ten cane strokes. ${ }^{13}$ The applicant appealed to the High Court at Bukoba, which on 6 June 2011 upheld the conviction but set aside the corporal punishment sentence. ${ }^{14}$ The High Court sentenced him to an additional six months in prison for contempt of court (for tearing a temporary

$4 \quad$ Protocol to the African Charter on Human and Peoples' Rights on the Establishment of an African Court on Human and Peoples' Rights, opened for signature on 10 June 1998, OAU Doc OAU/LEG/EXP/AFCHPR/PROT(III) (entered into force 25 January 2004) art 34(6). ('African Court Protocol'). As of January 2020 states that had made the declaration were Benin, Burkina Faso, Ivory Coast, Gambia, Ghana, Malawi, Mali, Tanzania and Tunisia.

5 It was reported on 5 December 2019 that the Government of the United Republic of Tanzania has withdrawn the right of individuals and non-governmental organisations to institute cases against it directly before the African Court on Human and Peoples Rights: 'Tanzania: Withdrawal of individual rights to African Court will deepen repression', Amnesty International, (News Article, 2 December 2019) $<$ https://www.amnesty.org/en/latest/news/2019/12/tanzania-withdrawal-of-individualrights-to-african-court-will-deepen-repression/>.

6 African Court Protocol (n 4) art 3.

7 African Charter on Human and Peoples' Rights, opened for signature 27 June 1981, 1520 UNTS 217 (entered into force on 21 October 1986).

8 International Covenant on Civil and Political Rights, opened for signature 19 December 1966, 999 UNTS 171 (entered into force 23 March 1976).

9 Universal Declaration of Human Rights, GA Res 217A (III), UN GAOR, UN Doc A/810 (10 December 1948).

10 Penessis (n 1) 22 [85].

11 ibid (n 1) 24 [91]-[92]; Anudo (n 2) 18 [80].

12 Penessis (n 1) 2-3 [4].

13 ibid.

14 ibid 3 [5]. 
travel document in court) and issued an order for his expulsion from the territory after serving the prison sentence. ${ }^{15}$

On 4 June 2012 the applicant further appealed to the Tanzania Court of Appeal. ${ }^{16}$ The Court of Appeal upheld the two years' prison sentence but set aside the six months' sentence for contempt of court, as well as the expulsion order, on the grounds that this fell under the authority of the Minister of Home Affairs. ${ }^{17}$ On 4 December 2012, the Minister of Home Affairs issued orders for his detention and deportation. ${ }^{18}$ These orders were not fulfilled upon the completion of his two years' prison sentence because, according to the respondent state, the applicant refused to cooperate and comply with the administrative procedures of the Tanzanian Immigration authorities and the South African embassy (which Tanzania stated was willing to recognise him as a national). ${ }^{19}$ Between 2013 and 2014, the applicant filed three applications for habeas corpus before the High Court in Bukoba and one in Dar es Salaam: two were struck out, one dismissed, and the other withdrawn by the applicant. ${ }^{20}$

The African Court received complaints in the case from several sources, in the form of letters from the applicant and by others on his behalf. ${ }^{21}$ The application was registered and served on the respondent state. ${ }^{22}$

The applicant claimed that his father and mother are Tanzanian, and that he was born in Tanzania and has lived there since his birth. ${ }^{23}$ He produced certified copies of a Tanzanian birth certificate and a temporary travel document as evidence of his citizenship. ${ }^{24}$ The respondent state objected that these documents were fraudulently acquired or forged, and that there was no record of his birth registration with the relevant agency - the Registration, Insolvency and Trustees Authority. ${ }^{25}$ The respondent state also alleged that the applicant held passports from both South Africa and the United Kingdom, in the names of Robert John Maitland and Robert John Rubenstein, indicating his place of birth as Johannesburg. ${ }^{26}$ Since dual citizenship is not permitted for adults under Tanzanian citizenship law, the possession of these other passports meant that even if he had previously held Tanzanian citizenship, he had now lost it. ${ }^{27}$ The respondent also asserted that the decisions in the courts, at the national level, were lawful, and the procedures had respected the applicant's rights. ${ }^{28}$

At the time of the hearing before the African Court, the applicant remained in Bukoba prison, where he had been for eight years. ${ }^{29}$

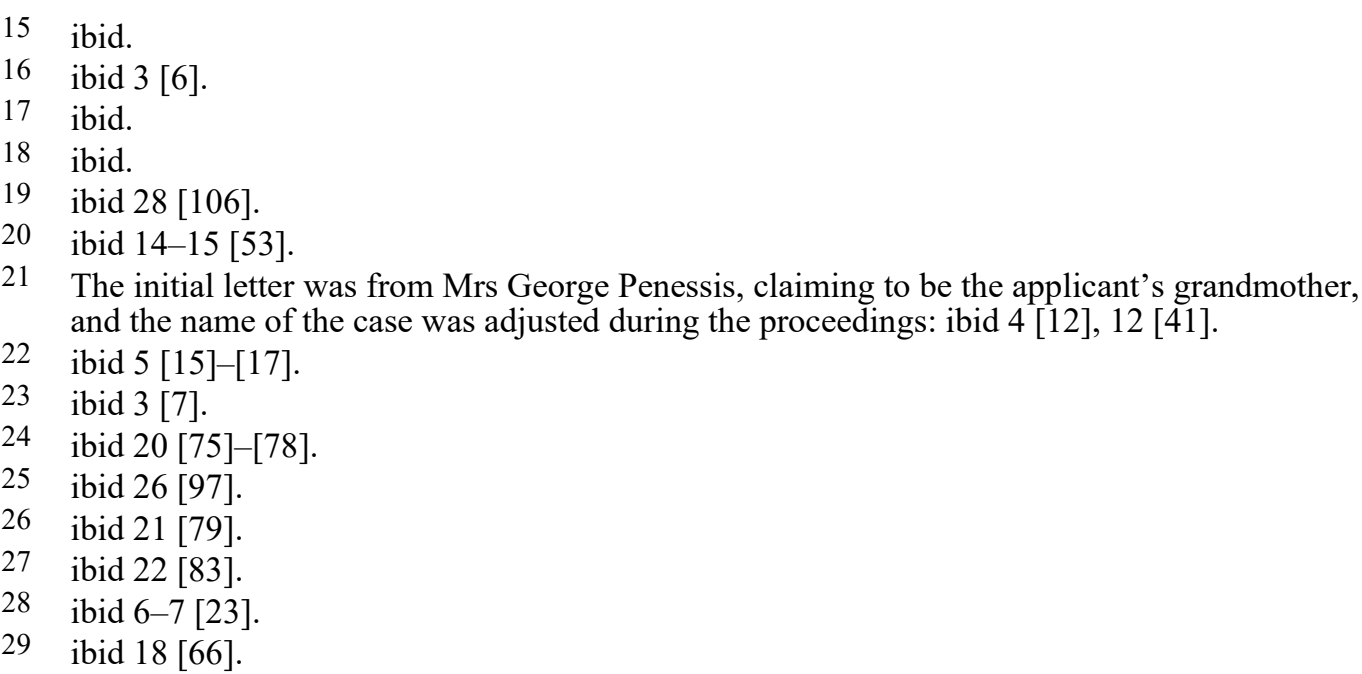




\section{ISSUES}

There were two main issues adjudicated in Penessis. First, whether or not the right of the applicant to Tanzanian nationality had been violated, and second, whether or not his arrest and detention were in conformity with the African Charter.

\section{HOLDING}

\section{A Admissibility}

Tanzania objected that the African Court had no jurisdiction to entertain the case on grounds of:

(i) failure of the application to constitute proper form and content as per rules of the African Court; ${ }^{30}$

(ii) failure by the applicant to exhaust local remedies; 31 and

(iii) failure by the applicant to file the application within reasonable time. ${ }^{32}$

The African Court dismissed all three objections, on the following grounds:

(i) the African Court adopted a flexible approach in relation to the form and content of an application; 33

(ii) the applicant had exhausted the remedies available, while the domestic procedures relating to the applicant's residence, deportation and detention were so intertwined that they could not be separated for these purposes; ${ }^{34}$

(iii) the reasonableness of the period within which an application must be made depends on particular circumstances of each case, and although two years and almost nine months elapsed between the Court of Appeal ruling and the communication to the African Court, the applicant had during that time been seeking domestic remedies through habeas corpus, and should not be penalised for those efforts. ${ }^{35}$

\section{B $\quad$ Merits}

The African Court determined the applicant's right to Tanzanian nationality (as guaranteed by art 5 of the Charter and art 15 of the UDHR) to have been violated by the respondent state. ${ }^{36}$

Consequent on this violation, the respondent state had also violated art 6 of the African Charter on the right to liberty and the security of the person, and art 12 of the African Charter on the right to freedom of movement and residence. ${ }^{37}$ The

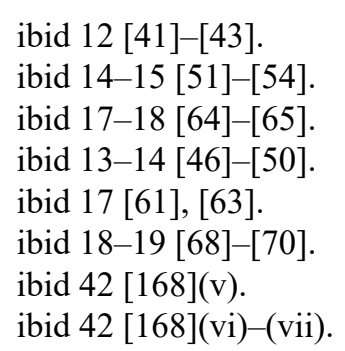


African Court ordered the immediate release of the applicant and payment of compensation to him and his mother. 38

\section{REASONING}

The African Court recalled its holding in Anudo that the UDHR is part of customary international law and is thus binding. ${ }^{39}$ This includes art 15 , which establishes the right to a nationality and prohibits the arbitrary deprivation of nationality. ${ }^{40}$ The African Court affirmed that states have the sovereign right to determine nationality, but that an arbitrary denial of the right to a nationality is incompatible with the right to human dignity, and statelessness must be avoided. It thus equated arbitrary denial of nationality with arbitrary deprivation. Accordingly, the African Court held that the right to nationality is encompassed within art 5 of the African Charter on the right to the respect of the dignity inherent in a human being and to the recognition of his legal status, supporting the jurisprudence of the African Commission on this point. ${ }^{41}$

The African Court then turned to the issue of burden of proof. The African Court reiterated the principle that anyone who alleges a fact must provide evidence to prove it. ${ }^{42}$ However, the African Court stated that there could be exceptions where the alleging party is not in a position to produce the required proof, or where the evidence is in the custody of the other party. ${ }^{43}$ In these cases, the African Court drew on decisions of the African Commission to hold that the state may be required to rebut a prima facie allegation. ${ }^{44}$ Noting that the applicant had always resided in Tanzania, the African Court invoked the principle of 'effective and solid link' enshrined in the Nottebohm Case before the International Court of Justice, ${ }^{45}$ meaning that the burden of proof should be reversed in this case.

The African Court then considered the facts in the case in light of the Tanzanian Citizenship Act. It reasoned that by producing a birth certificate, a temporary travel document, and testimony from a witness who stated that she was his mother, the applicant had shown a prima facie case that he was a citizen. It stated that, although the respondent state asserted that these documents were fraudulent, and that the status of the witness as his mother or as a Tanzanian citizen was not proved, it had not adduced evidence that the applicant was not a citizen. ${ }^{46}$ The African Court added that the respondent state had not demonstrated that the British and South African passports issued in different names in fact belonged to the applicant. ${ }^{47}$ In the circumstances where both parties were relying on certified copies,

the Court is of the opinion that the Respondent State, as a depository and guarantor of public authority and custodian of the civil status registry, has the necessary means to correctly establish whether the Applicant was a Tanzanian, South African or a British citizen. The Respondent State could also have obtained and produced

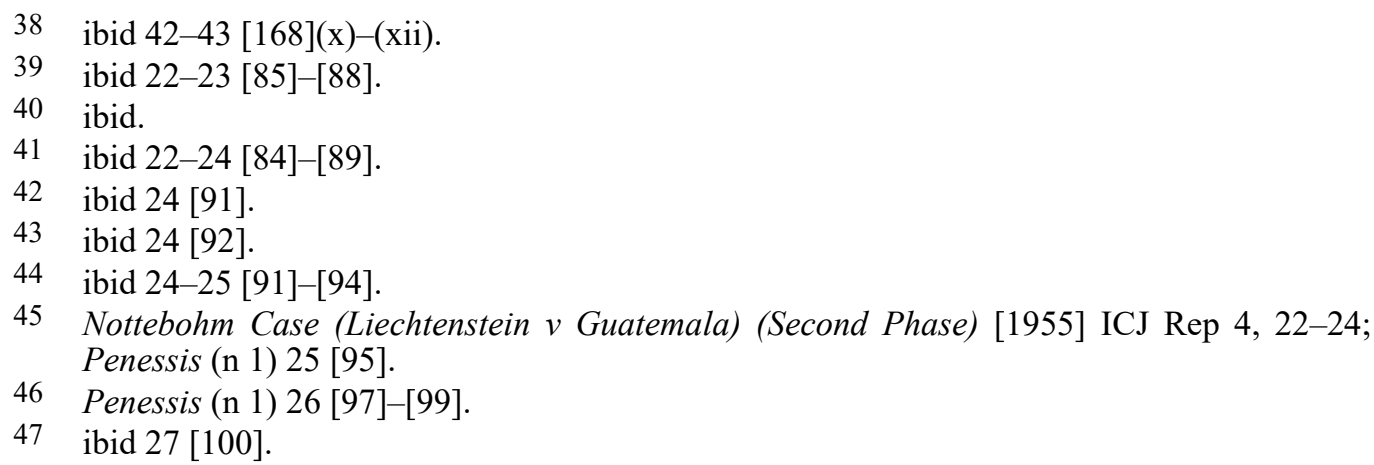


concrete evidence to support its assertion that the Applicant has other nationalities. ${ }^{48}$

The African Court therefore found that the applicant's right to Tanzanian nationality had been violated, contrary to art 5 of the African Charter and art 15 of $U D H R$.

The African Court went on to consider the applicant's right to liberty, as he remained in prison long after the expiry of a two-year prison term. Given that imprisonment was based on the assertion that he was not a national, and the African Court believed that the respondent state had not provided sufficient evidence that this was the case, his detention was therefore unlawful and in violation of art 6 of the African Charter ${ }^{49}$ For similar reasons, the African Court found a violation of art 12 of the African Charter on freedom of movement. ${ }^{50}$

\section{CONCLUSION}

The African Court in Penessis affirmed its commitment to protection of the right to a nationality established by art 15 of the $U D H R$, in line with the reasoning in Anudo. The African Court drew on African Commission jurisprudence to state that the right to a nationality is implied within art 5 of the African Charter on the 'right to the respect of the dignity inherent in a human being and to the recognition of his legal status'. ${ }^{51}$ It also affirmed views previously developed in its own decisions and those of the African Commission on the burden of proof in such cases. ${ }^{52}$ The African Court held that the burden of proof will be reversed, and fall on the respondent state, once a person has shown prima facie evidence that he or she holds the status claimed (in this case as a Tanzanian national). ${ }^{53}$

In reaching this view, the African Court restated that it 'is not an appeal court with respect to decisions rendered by national courts', but that

this does not preclude it from examining relevant proceedings in the national courts in order to determine whether they are in consonance with the standards set out in the Charter or any other applicable human rights instrument. ${ }^{54}$

The judgment does not, however, go on to consider the conduct of the proceedings in Tanzania, and whether they respected fair trial standards guaranteed by art 7 of the African Charter and by other applicable human rights treaties - including the question of burden of proof under domestic law. Rather, the African Court addressed directly the question of the validity of the documents and the strength of the respondent state's case. Assessing the evidence, the African

48 ibid 27 [102].

49 ibid 29 [109].

50 ibid 32 [125].

51 ibid 24 [89], citing Open Society Justice Initiative v Côte d'Ivoire (African Commission on Human and Peoples' Rights, Comm 318/06, 28 February 2015) 26 [96].

52 Penessis (n 1) 24 [91], citing Kennedy Owino Onyachi v United Republic of Tanzania (African Court on Human and Peoples' Rights, App No.003/2015, 28 September 2017) 37 [142]. See also at 25 [94], citing Institute for Human Rights and Development in Africa and Open Society Justice Initiative (on behalf of Children of Nubian Descent in Kenya) $v$ the Government of Kenya (African Committee of Experts on the Rights and Welfare of the Child, Comm 002/2009, 22 March 2011); Amnesty International v Zambia (African Commission on Human and Peoples' Rights, Comm 212/98, 5 May 1999) [41],

53 Penessis (n 1) 26 [96].

54 ibid 9 [32], [33]. 
Court considered that the Tanzanian government had not sufficiently established its case that the applicant was not a citizen.

Despite this failure to assess the proceedings in Tanzania against the African Charter, the principle of a reversed burden of proof underlined by the African Court is of critical importance in the context of Tanzania, as well as other African states, where very few hold identity documents. Birth registration in Tanzania has improved in recent years, but still stands at only a quarter of children under five years old. It is much lower for older generations. ${ }^{55}$ A national identity card has only recently been introduced, ${ }^{56}$ and only a small minority of Tanzanians have been issued a passport for international travel. ${ }^{57}$ In this context it can be virtually impossible for an ordinary resident to prove citizenship if the state chooses to question it and the burden of proof rests on the applicant. The African Court's judgments in both Penessis and Anudo establish the important principle that the key issue is the question of entitlement to citizenship rather than the possession of the correct supporting documents.

55 Tanzania: Demographic and Health Survey and Malaria Indicator Survey (Final Report, December 2016) 21, 26 <https://www.dhsprogram.com/pubs/pdf/FR321/FR321.pdf >.

56 The National Identification Authority was established in 2008, under the Registration and Identification of Persons Act No 111986 (Tanzania) amended 2014, and conducted a mass registration exercise from 2013-15: World Bank, 'The State of Identification Systems in Africa: Country Briefs' (Working Paper No 119065, January 2017) 53.

57 Halili Letea, 'Clock Ticks for 950,000 Holders of Old Generation Passports in Tanzania', The Citizen (Online, 29 July 2019) < https://www.thecitizen.co.tz/news/1840340-521496298txon/index.html>. 